\title{
The Role of Anthropogenic Landforms in Sustainable Landscape Management
}

\author{
Lucie Kubalikova ${ }^{1,2}$, Karel Kirchner ${ }^{1}$ (D) Frantisek Kuda ${ }^{1}$ and Ivo Machar ${ }^{3, *}$ (1) \\ 1 Institute of Geonics of the Czech Academy of Sciences, 60200 Brno, Czech Republic \\ 2 Department of Geology and Pedology, Faculty of Forestry and Wood Technology, Mendel University in Brno, \\ 61300 Brno, Czech Republic \\ 3 Department of Development and Environmental Studies, Faculty of Science, Palacky University Olomouc, \\ 77146 Olomouc, Czech Republic \\ * Correspondence: ivo.machar@upol.cz
}

Received: 27 June 2019; Accepted: 7 August 2019; Published: 10 August 2019

check for updates

\begin{abstract}
Anthropogenic landforms are attractive landscape structures. They are linked to the cultural elements of the landscape and they also support biodiversity on the landscape level. Concerning their position within heritage concepts, anthropogenic landforms can be seen as a bridge between natural and cultural heritages. This paper is focused on the relevance of anthropogenic landforms to landscape management and planning. The study is based on the concept of geomorphosites, which can be applied within sustainable management and the conservation of geomorphological heritage. The case study was applied in the urban area of Brno (Czech Republic). The results of the study indicated the importance of anthropogenic landforms for urban landscape conservation and sustainable tourism development. The assessment of landforms in the study area enabled to establish a set of recommendations for the sustainable management of anthropogenic landforms in Brno. This study suggested the assessment of anthropogenic landforms as a support tool for sustainable landscape management in urban areas.
\end{abstract}

Keywords: assessment; geomorphosites; sustainable tourism; conservation; Brno; Czech Republic

\section{Introduction}

Anthropogenic activities result in processes that considerably change the landscape [1] and even surpass the effectiveness of natural exogenic processes [2,3]. These activities often have great importance from the economic point of view (quarrying, mining fossil fuels, urban development, adjusting landscape for agriculture, construction of large dams which provide water reserves for industries and cities etc.), but from the conservation point of view, they lead to degradation of the landscape [4] and protected areas [5]. In some cases the landscape is completely remodeled and there is no evidence of past landforms [6,7]. In addition, these activities induce processes which would normally not exist in certain places [8], e.g., landslides and subsidence depressions, and these processes can also affect items of cultural heritage [9].

An anthropogenic landform is created by human activity, particularly by construction, excavation, hydrological interference and farming [10]. Anthropogenic landforms can be classified by the character of their impact: direct or indirect [11], and respectively intentional or unintentional (primary anthropogenic landforms and secondary anthropogenic landforms). But for the purposes of landscape management, the classification of the landforms based on origin type is probably the most suitable [12].

Specific anthropogenic processes result in anthropogenic landforms (e.g., quarries, pits, communication cuttings and underground landforms) that can be considered important from the 
scientific, educational, cultural, historical, environmental and tourism point of view [13-15]. These landforms have multiple functions:

- They can be seen as elements that increase the overall landscape diversity [16] and positively influence biodiversity $[17,18]$, especially disused quarries and flooded pits);

- They provide information about landscape changes and modifications made in the past, and these can be an important resource for understanding the cultural and technical level of a society [19,20];

- $\quad$ They support an ecosystem service provisioning [21];

- They allow us to trace the use of geodiversity in the past and interpret cultural heritage in relation to abiotic nature [22], including the involvement of local communities [23,24] based on applying of historical ecology [25];

- $\quad$ They possess the potential for developing sustainable forms of tourism (or geotourism), which can positively affect local economic development [26,27] — they can be visually attractive [28] or allow us to interpret the technical aspects of using geodiversity resources, e.g., mining and industrial tourism $[29,30]$;

- They allow us to observe stratigraphical, tectonic, palaeopedological and other Earth science features that would normally remain hidden and unrecorded in the literature or on geological maps [31,32] and the information can be used in both formal and informal education, and it is important from the conservation point of view [33];

- $\quad$ Landforms can be considered as an important stepping stones for biological species sensitive to fragmentation of landscape [34,35];

- Specific anthropogenic landforms form an inseparable part of items of cultural heritage, e.g., earth fortifications and ramparts and irrigation channels [36,37];

- In urban areas, the anthropogenic landforms allow us to interpret urban development [38] and they are an inseparable component of urban landscapes [39].

The importance of anthropogenic landforms is indisputable, however their position within heritage concepts still remains a subject of discussion. The Convention concerning the protection of the world's cultural and natural heritage [40] includes some anthropogenic landforms in the cultural heritage: "works of man or the combined works of nature and man, and areas including archaeological sites which are of outstanding universal value from the historical, aesthetic, ethnological or anthropological point of view." The guidelines for the inclusion of specific types of property on the World Heritage List [37] also specify cultural landscapes and heritage canals. Specific anthropogenic landforms can be respected as a full-value part of the mining heritage [41,42]. This type of heritage is considered a subset of cultural heritage. However, the natural aspects of mining are also included (geological settings, type of material extracted) and anthropogenic modifications, landforms and processes (e.g., silted dams, open cuts, embankments and mounds, tailings dumps) are taken into account as well [43].

A special situation can be found in urbanized areas that are usually heavily affected by anthropogenic transformations of the relief and thus the abundance of anthropogenic landforms is high there [11]. In these cases, the anthropogenic landforms can be respected as a component of "urban geoheritage" [44,45]. Some authors [46] include anthropogenic landforms in the concept of "geomorphological heritage" or "geocultural heritage", using examples such as Petra (Jordan) or Cappadocia (Turkey). These sites are clearly not natural, yet they have strong links to geological and geomorphological aspects. According to Coratza and Hobléa [47], geomorphological heritage is defined as the set of landforms worthy of being protected and transmitted to future generations. Geomorphological heritage includes not only geomorphological objects sensu stricto, but also cultural (man-made) components with their heritage value determined by geomorphological conditions. In this context, anthropogenic landforms can be seen as specific examples of geomorphosites [48] and defined as "geomorphological objects or wider landscapes. They may be modified, damaged, and even destroyed by the impact of human activities", or they can be "geocultural sites" (a term proposed by [46] and used e.g., by [49]), which are defined as places where geoheritage interacts with cultural 
assets. Thus, specific anthropogenic landforms can be assessed through similar methods to those used within the geomorphosite concept.

Geomorphosite assessment has been widely used in natural and rural areas [50,51]. However, assessment methods within urban areas are rather scarce [52]. In addition, the use of the geomorphosite concept for anthropogenic landforms has not yet been applied, mainly due to the ambiguous position of anthropogenic landforms within heritage concepts. This paper intent to fill the following knowledge gaps:

(1) the possibility of using the geomorphosite concept for anthropogenic landforms as a special case of geomorphological heritage

(2) the application of the geomorphosite assessment in an urban area.

Based on the assessment of specific anthropogenic landforms in Brno (Czech Republic), we have designed the management proposals for sustainable use (with an emphasis on conservation issues and sustainable tourism development) that can be applied in other urban areas.

\section{Methods and Material}

\subsection{Methodological Approach}

In recent decades, numerous geomorphosite assessment methods have been introduced and used, especially in geoheritage and geotourism studies [44,53-63]. Later, these methods were critically reviewed and discussed in several papers [64-68]. All the methods respect the links between geology, culture and tourism [69,70], and they also accept the holistic approach to geotourism [71-73].

In this study, the assessment of anthropogenic landforms is based on expert-based approach [74-76]. For the study we decided to apply a set of criteria based on methods presented by Pereira and Pereira [56] and by Reynard et al. [51]. Both methods have been verified in several studies and used on different types of sites, including the geocultural ones [49]. As the assessment is intended for anthropogenic landforms, minor changes were made and supplements added:

- Exclusion of the "palaeogeographic importance" criterion within the Scientific values: in the case of anthropogenic landforms, the palaeogeographical value can be a discriminative criterion as the specific anthropogenic landforms are recent and therefore they have a low value in terms of the possibilities for reconstructing the palaeogeography of the studied area [51].

- Inclusion of the "educational value" criterion: education and learning represent an important tool for conservation activities [77]. They play an essential role in the development of sustainable forms of tourism, especially geotourism [78], so they should be assessed separately.

- Inclusion of the "diversity of cultural values" criterion: anthropogenic landforms always have a relationship to cultural aspects (as they are created by human activity or refer to the use of natural resources by people). Originally the methods allowed only the assessment of present/absent and did not reflect the diversity and number of these added values and elements-that's why the criterion of "diversity of cultural values" was added.

- Exclusion of the "aesthetic value" criterion: generally, this criterion is assessed by using visibility, number of colours, or the structuration of a space and it is considered relatively subjective [79]. In the case of anthropogenic landforms, this aspect is very difficult to assess due to the diversity of origin types of landforms. The criterion "visibility" partly substitutes for the "aesthetic value".

Concerning the terminology, Reynard et al. [51] distinguish between the scientific "values" and management "characteristics", and the educational and tourism "potential". However, the definition of geomorphosite [79] uses the term social/economic values, under which we can include these aspects (tourism, management, education, conservation). Thus, for the purposes of this study we use the term value to avoid ambiguities.

A numerical value can be assigned to every criterion. A total value is represented by the sum of all the values. The criteria used for the assessment are presented and briefly explained in Table 1. 
Table 1. Assessment method for anthropogenic landforms.

\begin{tabular}{|c|c|c|}
\hline Values & Criteria/Questions & Numerical Assessment Proposal \\
\hline \multirow[t]{4}{*}{ Scientific value } & $\begin{array}{l}\text { Integrity or current status of the site: related to the conservation status of the } \\
\text { main elements }\end{array}$ & $\begin{array}{l}\text { 1—conserved } \\
0.5 \text {-partly conserved } \\
0 \text {-damaged }\end{array}$ \\
\hline & $\begin{array}{l}\text { Diversity of the Earth science features: a number of different elements with } \\
\text { scientific interest }\end{array}$ & $\begin{array}{l}1-4 \text { and more different features } \\
0.5-2-3 \text { features } \\
0-1 \text { feature }\end{array}$ \\
\hline & Rarity: number of similar sites in the area of study & $\begin{array}{l}\text { 1—the site is unique within study area } \\
0.5 \text { - there are } 2 \text { or } 3 \text { similar sites } \\
0 \text {-more than } 3 \text { similar sites }\end{array}$ \\
\hline & $\begin{array}{l}\text { Scientific knowledge of the site: the existence of published scientific studies } \\
\text { about the site }\end{array}$ & $\begin{array}{l}1 \text {-world known site } \\
0.5 \text {-regionally/nationally known site, several scientific papers } \\
0 \text { - the site has been researched marginally }\end{array}$ \\
\hline \multirow[t]{2}{*}{ Educational value } & $\begin{array}{l}\text { Exemplarity and representativeness: capacity of a site to illustrate Earth } \\
\text { science elements or processes, possibility for people with no geological } \\
\text { background to understand the elements and processes }\end{array}$ & $\begin{array}{l}\text { 1-good exemplarity and representativeness of the features } \\
0.5 \text {-features are comprehensible, but short explication is needed } \\
0 \text {-features are not legible to the lay public; professional explication is needed }\end{array}$ \\
\hline & Presence of educational facilities, e.g., educational trails or information panels & $\begin{array}{l}\text { 1- presence of educational trails or information panels with relevant information } \\
0.5 \text { - existing educational facilities but with limited information } \\
0 \text {-no educational facilities on the site }\end{array}$ \\
\hline \multirow[t]{4}{*}{ Tourist value } & Accessibility & $\begin{array}{l}\text { 1-access without problems } \\
0.5 \text {-limited access (e.g., only with permission or with special equipment) } \\
0 \text { - site is inaccessible to the public (or access is possible at own risk) }\end{array}$ \\
\hline & Safety: high or low risk conditions for visitors & $\begin{array}{l}\text { 1—safety is not a problem } \\
0.5 \text {-some specific limitation (e.g., the risk of landslides) } \\
0 \text {-visiting site is not recommended and it is dangerous }\end{array}$ \\
\hline & $\begin{array}{l}\text { Tourist infrastructure: facilities for receiving tourists (accommodation, food, } \\
\text { toilets) }\end{array}$ & $\begin{array}{l}\text { 1-tourist infrastructure situated within walking distance } \\
0.5 \text {-limited tourist infrastructure is accessible } \\
0 \text {-no tourist infrastructure }\end{array}$ \\
\hline & $\begin{array}{l}\text { Viewpoints and visibility: the conditions for observation of all the elements on } \\
\text { the site }\end{array}$ & $\begin{array}{l}\text { 1-more than } 3 \text { different viewpoints } \\
0.5-1-3 \text { viewpoints } \\
0-\text { no viewpoint, the visibility is limited }\end{array}$ \\
\hline
\end{tabular}


Table 1. Cont

\begin{tabular}{|c|c|c|}
\hline Values & Criteria/Questions & Numerical Assessment Proposal \\
\hline \multirow[t]{2}{*}{ Added value } & $\begin{array}{l}\text { Ecological aspect: the relevance from the ecological or biological point of view } \\
\text { (e.g., species/ecosystems that exist here due to the existence of } \\
\text { landform/anthropogenic activity) }\end{array}$ & $\begin{array}{l}\text { 1-yes, there are some specific ecological features } \\
0 \text {-without specific ecological features }\end{array}$ \\
\hline & $\begin{array}{l}\text { Cultural aspects: a number of different cultural aspects (e.g., historical } \\
\text { aspect- evidence of social/economic/industrial changes and development; } \\
\text { artistic aspect- - site as an inspiration for artists; architectonical aspect-visible } \\
\text { evidence of the use of material especially from mining landforms; presence of } \\
\text { religious features on the site; geomythological aspect—-myths about the site; } \\
\text { technical aspects etc.) }\end{array}$ & $\begin{array}{l}2-5 \text { and more different cultural aspects } \\
1.5-4 \text { different cultural aspects } \\
1-3 \text { different cultural aspects } \\
0.5-2 \text { different cultural aspects } \\
0-1 \text { cultural aspect }\end{array}$ \\
\hline \multirow[t]{2}{*}{ Conservation value } & $\begin{array}{l}\text { Existing legislative protection (site declared as natural monument or } \\
\text { reservation, part of the large protected landscape area, protected as a } \\
\text { significant landscape element, cultural protection etc.) }\end{array}$ & $\begin{array}{l}\text { 1-existing legislative conservation } \\
0.5 \text { - the site is proposed for conservation or is registered as an important } \\
\text { landscape element } \\
0 \text {-no legal protection or proposals for conservation }\end{array}$ \\
\hline & $\begin{array}{l}\text { Current threats [80]: the existence of any threats that can lead to the damage } \\
\text { of the site (both natural respectively natural threats induced or supported by } \\
\text { human activity that can lead to the destruction of a site or its degradation or } \\
\text { disappearance of specific geo-features, e.g., vegetation growth, invasive } \\
\text { species, landslides) and anthropogenic (e.g., dump fill, vandalism, } \\
\text { "revitalization" that can cause disappearance of specific Earth science and } \\
\text { related features) }\end{array}$ & $\begin{array}{l}\text { 2-no threats, risks or hazards } \\
\text { 1.5- existing threats, but the risk is low or already being managed } \\
\text { 1—existing threats with an average or high risk, but there is a certain conception } \\
\text { how to manage them or how to mitigate the impacts } \\
0.5 \text { - existing threats with high risks which are not managed and resolved } \\
0 \text { - currently the site is in danger, there are some processes that can lead to its } \\
\text { devastation }\end{array}$ \\
\hline
\end{tabular}




\subsection{Study Area and Selected Anthropogenic Landforms}

The study area (town Brno) is situated in the region of southern Moravia (southeastern part of the Czech Republic). It lies on the contact point of two different units: Variscan Central Europe (respectively the Bohemian Massif) and Alps-Carpathian area (respectively the Carpathian Foredeep), so the geology and landscape of the area is quite complicated and varied. Most geological eras are represented in the relatively small area of the city: The Cadomian Brno Massif (composed of metamorphosed basalts [ 725 Ma old] and granodiorites), the Paleozoic cover (represented by Devonian basal clastic sediments), Jurassic limestones, Neogene sediments of the Carpathian Foredeep (Ottnangian gravels, Badenian calcareous clays) and Quaternary sediments (represented by loess, fluvial deposits and anthropogenic sediments) $[81,82]$.

The study area is in two different geomorphological provinces: the Bohemian Highlands and the Western Carpathians $[83,84]$, and this suggests that there will be a rich variety of landforms. In the northern and central parts, the relief is tectonically influenced (occurrence of horsts and grabens and tectonically conditioned valleys) and more pronounced; the southern part is rather flat and was mainly formed during the Neogene and Quaternary. The uniqueness of Brno's relief lies in the "chessboard" layout of the ridges and valleys, and this has influenced the situation concerning communication, buildings and urban development in general.

The relief of the study area is strongly influenced by anthropogenic activity (the occurrence of numerous urban/residential, communications, industrial, mining and other anthropogenic landforms). The exploitation of construction materials (loess, sand, building stone-limestone, sandstone, conglomerate, granodiorite, metabasalt) can be traced back to the 12th century and it has markedly influenced the landscape [85-87].

The choice of representative landforms was based on a detailed literature review and a field survey using the genetic aspect. Nearly every group of anthropogenic landforms is represented. As diversity exists within the groups, we selected various types within each group. In some cases, two or more types of anthropogenic landforms are present on the site. In total, 21 anthropogenic landforms were selected for the assessment. For details about the sites, see Table 2.

Table 2. Selected sites and anthropogenic landforms.

\begin{tabular}{ll}
\hline \multicolumn{1}{c}{ Number and Name } & \multicolumn{1}{c}{ Type of Anthropogenic Geomorphosite and Short Characteristics } \\
\hline S1 Červený kopec A & mining (loess pit) \\
S2 Červený kopec B & mining (conglomerate and sandstone quarries) \\
S3 Hády—plain & mining (medieval Devonian limestone quarries) \\
S4 Hády-upper bench & mining (recent Jurassic/Devonian limestone quarry) \\
S5 Hády-Rǔženin lom & mining (limestone and granitoid quarry), communication/industrial (tunnels) \\
S6 Žabovřesky quarry & mining (metabasalt quarry) \\
S7 Černovice sandpit & mining (sand pit with occurrence of clays and gravels) \\
S8 Stránská skála & mining (Jurassic limestone quarry) and industrial (underground factories) \\
S9 Zelný trh-labyrinth & residential (system of cellars) \\
S10 Ossuary of St. James & funeral (underground spaces) \\
Church & military (war or nuclear bomb shelter) \\
S11 Bunker 10-Z & residential/military (ramparts, banks, trenches), communication/traffic (old hollow ways) \\
S12 Obřany castle & water management (reservoirs, millraces, boreholes, wells) \\
S13 Ř́č́ka valley & water management (underground water reservoirs) \\
S14 Water reservoirs Tvrdého & water management/littoral (abrasion cliffs in loess) \\
S15 Abrasion cliffs at Brno dam & agricultural (terraces), communication/traffic (old hollow ways) \\
S16 Bosonožský hájek & communication/traffic (road cutting in granodiorites) \\
S17 Jedovnická street cutting & communication/traffic (road cutting in the rocks of Brno massif) \\
S18 Vejrostova street cutting & communication/traffic (artificial communication embankments) \\
S19 Old highway & communication/traffic (remains of railway embankments) \\
S20 Tišnovka railway & urban/communication (outcrops of the rocks of Brno massif which has been considerably \\
S21 Úvoz & remodelled by human activity-the part of the site does not exist due to road \\
& construction) \\
\hline
\end{tabular}




\section{Results}

\subsection{Results of the Assessment}

The landforms were assessed using the method outlined above. The results of the numerical assessment are presented in Table 3 and Figure 1.

Table 3. The results of assessment (interpretation and ranking in the following text).

\begin{tabular}{|c|c|c|c|c|c|c|}
\hline Sites & $\begin{array}{l}\text { Scientific } \\
\text { Value }\end{array}$ & $\begin{array}{c}\text { Educational } \\
\text { Value }\end{array}$ & $\begin{array}{l}\text { Tourist } \\
\text { Value }\end{array}$ & $\begin{array}{l}\text { Added } \\
\text { Value }\end{array}$ & $\begin{array}{l}\text { Conservation } \\
\text { Value }\end{array}$ & Total Value \\
\hline S1 (Červený kopec A) & 3.5 & 1 & 2.5 & 1.5 & 2 & 10.5 \\
\hline S3 (Hády—plain) & 1.5 & 1 & 3 & 1.5 & 2.5 & 9.5 \\
\hline S4 (Hády-upper bench) & 2.5 & 1 & 3 & 1 & 1.5 & 9 \\
\hline S5 (Hády-Růženin lom) & 2.5 & 2 & 2.5 & 1.5 & 2 & 10.5 \\
\hline S8 (Stránská skála) & 4 & 1.5 & 3 & 3 & 2.5 & 14 \\
\hline S9 (Zelný trh-labyrinth) & 0.5 & 1 & 3 & 1.5 & 2 & 8 \\
\hline S10 (Ossuary St. James) & 2 & 1 & 3 & 1 & 2 & 9 \\
\hline S11 (Bunker 10-Z) & 1.5 & 1.5 & 2.5 & 1 & 1.5 & 8 \\
\hline S12 (Obřany castle) & 1.5 & 1 & 3 & 1.5 & 1.5 & 8.5 \\
\hline S17 (Jedovnická street cutting) & 1.5 & 1 & 2.5 & 0 & 1.5 & 6.5 \\
\hline S18 (Vejrostova street cutting) & 1 & 1 & 2.5 & 0 & 2 & 6.5 \\
\hline S19 (Old highway) & 1.5 & 0.5 & 3 & 1 & 2 & 8 \\
\hline S20 (Tišnovka railway) & 1 & 2 & 4 & 1 & 2 & 10 \\
\hline S21 (Úvoz) & 1.5 & 1 & 3 & 1 & 1.5 & 8 \\
\hline
\end{tabular}

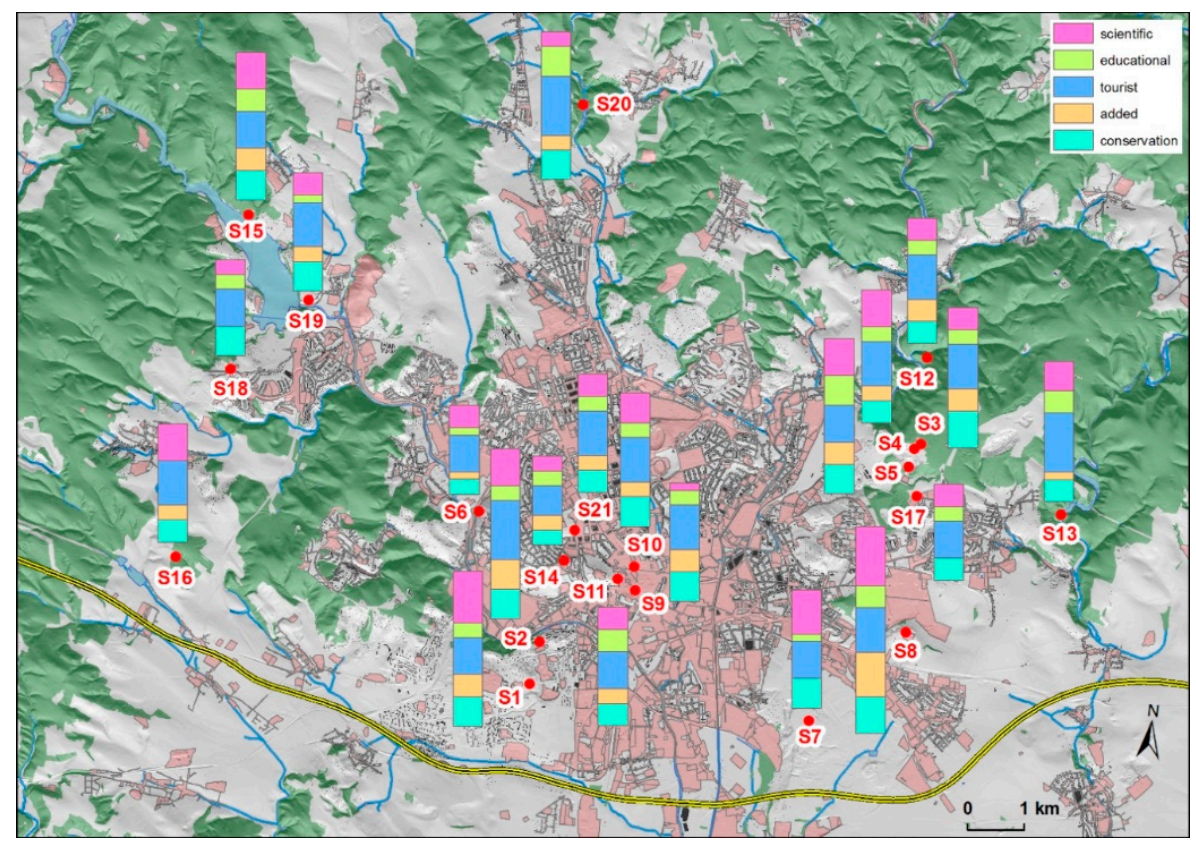

Figure 1. The results of the assessment of the anthropogenic geomorphosites within Brno (numbers S1-S21 see Table 3).

Based on the assessment, the basic statistical analysis was carried out. A simple comparison between the groups of values was elaborated. Figure 2 presents crossed values and linear correlations (r) for each pair of measurements. Between scientific/tourist value and scientific/educational value, there is no significant correlation. The correlation between scientific and conservation value is higher 
$(r=0.3559)$, however it is still considered weak. But these preliminary results cannot be regarded as conclusive because the number of assessed geomorphosites is relatively low. In addition, the interpretation of relationships requires more detailed analysis.
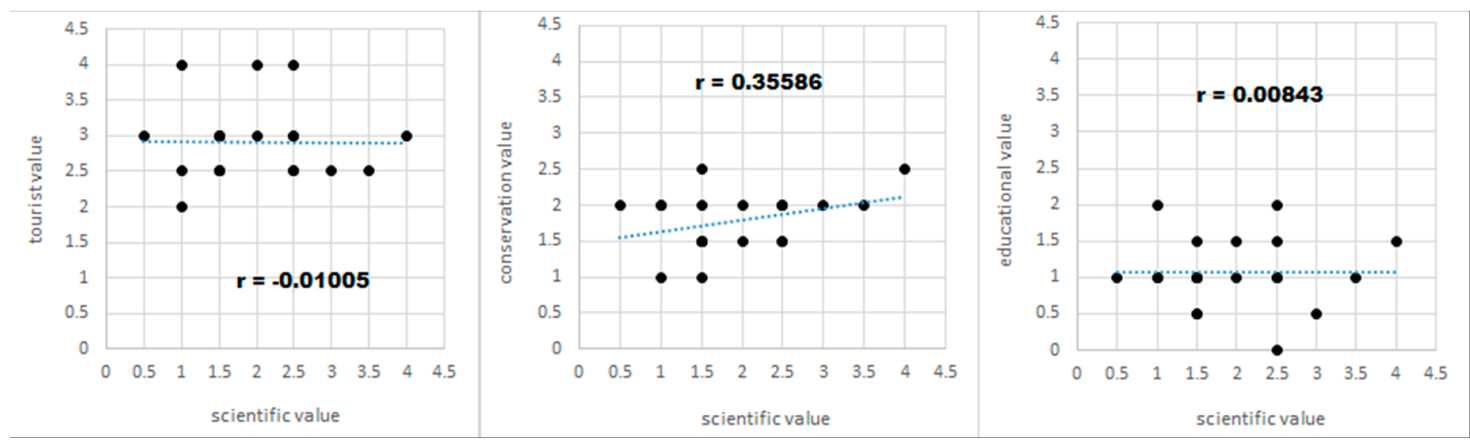

Figure 2. Graphic presentation of the comparison between scientific and tourist values, and conservation and educational values.

The Spearman's rank correlation coefficient for the first approach revealed no significant correlation between scientific/tourist value $(\rho=0.014)$ and scientific/educational value $(\rho=0.016)$. The correlation between scientific and conservation value is slightly higher $(\rho=0.273)$, however it is still considered weak. But these preliminary results cannot be regarded as conclusive because the number of assessed geomorphosites is relatively low.

\subsubsection{Scientific Values}

High scientific value in this study was attributed to the mining landforms due to the high diversity (because of these landforms numerous Earth science features were observable). It was supported by local scientific knowledge (these landforms are often used for geological mapping or they were the subject of specific research - both geoscientific and archeological). Low scientific value was generally attributed to the underground anthropogenic landforms and road cuttings. In the case of underground anthropogenic landforms, the low value was caused by the low diversity of Earth science features and the low geoscientific knowledge of the site. In the case of communication/traffic landforms, the low scientific values were mainly caused by low scientific knowledge (there were only mentions of them in the documentation of the municipal office in Brno or on geological maps) and by the fact that the number of Earth science features were not considered as unique.

\subsubsection{Educational Values}

The educational value of the anthropogenic landforms is independent of the landform genesis and it does not have a strong link to the scientific value (see Figure 2). The high educational value is usually related to the easy legibility of the landforms. Low scores of educational value are caused by limited visibility or absence of educational facilities on the site. In some cases the landforms are visible and recognizable in the terrain, but a professional explication is needed as there are various interpretations of the landforms origins and there is the possibility of misunderstanding some of them.

\subsubsection{Tourist Values}

The tourist value of the anthropogenic geomorphosites probably does not depend on the landform genesis and there is no clearly defined link to or dependence on scientific value (see Figure 2). A high tourist value for the sites is attributed to sites with good accessibility and safety, and the presence of a developed tourist infrastructure, including numerous viewpoints from where the landforms can be observed. Nevertheless, in some cases, the safety reasons contribute to the low tourist value. 


\subsubsection{Added Values}

The high added values were generally attributed to the mining geomorphosites, particularly due to the many and diverse cultural aspects and important ecological aspects. In contrast, the lowest added value was attributed to road cuttings and other communication landforms.

\subsubsection{Conservation Values}

There is a correlation between scientific and conservation value, however the conservation value probably does not depend on landform genesis and this is proven by the results of the assessment. The mining sites usually reached a high score in conservation value because they are already legally protected, which means that possible threats and risks are somehow managed. Nevertheless, relatively high conservation values were also achieved by the other sites of different origin. Legal protection is usually related to surface (not underground) sites, but there are also higher risks and threats (e.g., conflicts with vegetation, risks of degradation of the landforms due to natural or anthropogenic processes, inappropriate use of the landform that can lead to its destruction). The underground spaces usually have no legal protection, but there are lower risks of damage. Nevertheless, there can be conflicts with urban development and landscape planning that can suggest some further threats.

\subsubsection{Total Values}

Generally, the highest total values were obtained by mining sites. High total values can indicate that the sites have a considerable tourist and educational potential and they are very valuable from the conservation point of view. However, the sites with high total values are usually already legally protected and partly used for (geo)tourism, so in this case the high total value alerts us to the necessity of preserving the current positive status, and to ensure rational and sustainable use of the site and existing conservation management measures. Practically it means that the care plan (planning document for the protected site) should be consistently maintained in the future and different sources of finance for the preservation activities should be sought. The preservation of the current conservation status, including the protective buffer zones has to be maintained and respected in urban planning documentation. The low total score indicates that the scientific and added values of the sites are average, the tourist value is relatively low and the conservation value is also low due to the presence of threats that can endanger or damage (or destroy) the sites.

\subsection{Proposals for the Management of the Anthropogenic Landforms}

Based on the results, proposals for sustainable urban landscape management and a strategy of urban landscape conservation are presented.

In the case of a site with a high scientific value, detailed documentation of the site and the establishment of legal protection are necessary in order to avoid the possible loss of this value. Legal protection then ensures the inclusion of the site in urban planning documentation and strategies. The use of the sites with a high scientific value for geotourism purposes should be developed in relation to the current status or conservation of the site. In the case of average and low scientific values, the site should at least be documented.

In the case of high educational value, it is crucial to ensure sustainable educational use (in the case where there is already an educational use, e.g., by adopting the visitors' orders or rules) and to emphasize the relationship of the educational value to the conservation aspect (mentioning the importance of protection when using the site for educational proposals). In the case of average or low educational value and high scientific value, the development of an adequate tourist and interpretative infrastructure which respects the geoconservation aspects is desirable. The sites with high and average educational values are an important resource for local schools and informal educational activities, so ensuring the appropriate educational use of the sites is linked to the quality of education in urban areas. 
In the case of a high tourist value of a site, it is necessary to assure the sustainable use of the site by setting the links between tourist/recreational use and conservation activities in order to avoid potential conflicts of interest and to establish a balance between conservation needs and tourist use. It is also necessary to ensure the future treatment and management of the tourist infrastructure regarding visitor safety and to inform visitors about possible risks. In the case of low tourist value but high scientific, educational or added values, the development of an adequate tourist infrastructure can be considered, but always with respect for the conservation aspects.

In the case of high added values it is important to set the links between added values and scientific values - in the case of currently protected sites or sites proposed for legal protection this can help with the acceptance of conservation measures. The added values can also be used for geoeducational purposes. In the case of low added values, it is possible to combine and increase added values (e.g., use of the site for cultural events) for future tourism development.

In the case of high conservation value, ensuring the sustainability of the positive status of the site (including financial measures), it is necessary to offer information to visitors about management measures from the geoconservation point of view and to ensure the acceptance of conservation values within landscape planning. In the case of low conservation value, it is crucial to adopt immediate measures to stabilize the site (in the case of high scientific value) and to analyse the relationships between the behaviour of visitors and the current status of the site, including anthropogenic threats in general (in the case of average or high tourist value). It is also desirable to include the public in planning the management of a site and to develop volunteering as regards management proposals or lack of finances.

\section{Discussion}

Total value must be considered in the context of particular values of cultural landscape [88]. A high total value did not automatically mean that a site was suitable for geotourism and worthy of conservation, but it could indicate the need for the preservation of the current positive status [89]. Similarly, the sites with low total value may spark discussion about new possibilities for rational and sustainable use, which can increase their value and reduce the uncertainties [90]. One methodological approach is to strengthen conservation measures-these can decrease potential threats to the site, but when there is a conflict of interest or conflicts with urban development where considerable changes to or destruction of a site is in the public interest, the reinforcement of conservation is disputable. Another approach is to include the endangered sites in so-called rescue geological and geomorphological research activities [91-93], with the aim of keeping scientific information which can serve educational purposes, even after serious damage or destruction of a site. This study is generally based on holistic approach, which includes biosphere alternations caused by human activities [94-96].

A comparison of the presented study with other studies that used geomorphosite assessment methods would probably be a bit misleading as the sites included in the presented study were of anthropogenic origin and other studies mainly consider natural sites, e.g., [59,61,97]. Thus, we made a comparison in the context of the relationships between particular site values: while in the case of natural areas and natural sites, the higher the scientific value, the higher the tourist value [58,97], in the case of anthropogenic sites this correlation is weak (Figure 2). However, in order to prove this hypothesis, a more detailed study should be done (with a higher number of assessed geomorphosites) in the future. It is a similar situation with the relationships between scientific and conservation values and scientific and educational values where there was no statistically proved correlation.

Proposals for a management strategy and the sustainable using the sites of anthropogenic origin have been the subject of several studies [98]. These studies were mainly focused on abandoned quarries in rural areas, however some proposals for landscape management, including conservation aspects, are common. Margiotta and Sanso [27] confirmed that some abandoned quarries are part of the natural and cultural heritage as an important resource for geotourism development. Baczynska et al. [28] also confirmed these landscape forms (quarries) as elements that enrich the value of particular areas 
in terms of tourism. Authors of the study $[26,29]$ concluded that abandoned quarries could be of geoconservation significance and some of them were very important for geoscientific tourism. Prosser [33] suggested that quarries were important sites from a scientific point of view and should be conserved as protected areas and highlighted the importance of involvement of local communities and stakeholders to the geomorphosite management in order to better support of conservation effort. The proposals for anthropogenic landforms in urban areas differ, especially in conservation-we suggested that scientifically valuable sites should immediately be conserved in order to avoid their loss and conflicts with urban development. All the sites should be seriously documented in case of their loss. Other anthropogenic landforms have not yet been the subject of geomorphosite assessment in literature.

\section{Conclusions}

Human impact on relief does not always have to be destructive; on the contrary, some anthropogenic landforms (thanks to their scientific, educational, cultural, historical, tourist or other values) are important and indisputable parts of the natural and cultural heritage of certain areas and should be treated and assessed accordingly. The use of geomorphosite concepts for the assessment of sites with anthropogenic landforms is one of the support tools for establishing future sustainable landscape management and conservation measures. Based on the assessment, some final remarks can be presented:

- Anthropogenic landforms can achieve high scientific value, they can be included in the natural and cultural heritage and thus can be the subject of conservation efforts;

- $\quad$ Setting legal protection for these sites ensures their acceptance by urban strategic planning and development;

- The educational value of anthropogenic landforms within urban areas should be reconsidered and accepted as an important resource for on-site learning, and for both formal and informal education;

- Anthropogenic landforms possess the potential for the development of sustainable forms of tourism-they can represent an interesting alternative to the traditional tourist destinations, and as such they should also be treated as a tourist resource;

- Anthropogenic landforms are typical for their close relationship between natural and cultural features. The promotion of the links between scientific and added (cultural) values may help in the acceptance of the need for conservation measures by local communities and authorities.

The results of anthropogenic landform assessment can serve landscape planning purposes and can assist in arguments for conserving specific sites (e.g., registration of new important landscape elements, declaration of new protected monuments), as it has been applied in studies [99,100]. Likewise, they can justify the inclusion of conservation, tourism, education and related activities in the local/regional landscape, as well as land use planning and development strategies. Anthropogenic landform assessment can help to avoid potential future conflicts of interest and even the loss of valuable sites.

Author Contributions: Conceptualization, L.K., I.M. and K.K.; methodology, L.K., F.K.; writing—original draft preparation, L.K., K.K., I.M.; writing-review and editing, I.M., L.K., K.K., F.K.; visualization, F.K.

Funding: This research was funded by the Ministry of Culture of the Czech Republic as a part of the NAKI II program, grant number DGB 16P02B014 (Cultural heritage of landscape of the Archdiocese of Olomouc-research, presentation and management).

Conflicts of Interest: The authors declare no conflicts of interest.

\section{References}

1. Machar, I. Changes in ecological stability and biodiversity in a floodplain landscape. In Applying Landscape Ecology in Conservation and Management of the Floodplain Forest (Czech Republic); Accession Number: WOS:000325436900004; Machar, I., Ed.; Palacky University: Olomouc, Czech Republic, 2012; pp. 73-87, ISBN 978-80-244-2997-7. 
2. Hooke, R.L.; Martín-Duque, J.F. Land transformation by humans: A review. GSAT 2012, 22, 4-10. [CrossRef]

3. Nir, D. Man, a geomorphological agent: An introduction to anthropic geomorphology. Earth Surf. Process. Landf. 1985, 10, 418.

4. Goudie, A. The Human Impact on the Natural Environment: Past, Present and Future, 6th ed.; Blackwell Publishing: Hoboken, NJ, USA, 2006; ISBN 978-1-4051-2704-2.

5. Oprsal, Z.; Harmacek, J.; Pavlik, P.; Machar, I. What factors can influence the expansion of protected areas around the world in the context of international environmental and development goals? Probl. Ekorozw. 2018, 13, 145-157.

6. Szabó, J.; Dávid, L.; Lóczy, D. Anthropogenic Geomorphology: A Guide to Man-Made Landforms; Springer: Dordrecht, The Netherlands, 2010; ISBN 978-90-481-3057-3.

7. Kilianova, H.; Pechanec, V.; Brus, J.; Kirchner, K.; Machar, I. Analysis of the development of land use in the Morava River floodplain, with special emphasis on the landscape matrix. Morav. Geogr. Rep. 2017, 25, 46-59. [CrossRef]

8. Niemiec, D.; Duraj, M.; Marschalko, M.; Yilmaz, I. Conservation of Selected Churches in the Most Region and Karviná Region and their Significance for Geotourism. Procedia Eng. 2016, 161, 2276-2281. [CrossRef]

9. Pechanec, V.; Machar, I.; Pohanka, T.; Oprsal, Z.; Petrovic, F.; Svajda, J.; Salek, L.; Chobot, K. Effectiveness of Natura 2000 system for habitat types protection: A case study from the Czech Republic. Nat. Conserv. Bulg. 2018, 24, 21-41. [CrossRef]

10. Goudie, A.S. Anthropogenic landforms. In Encyclopedia of Geomorphology; Goudie, A.S., Ed.; Taylor \& Francis: Milton Park, UK, 2006; p. 1202. ISBN 0-415-32737-7.

11. Li, J.; Yang, L.; Pu, R.; Liu, Y. A review on anthropogenic geomorphology. J. Geogr. Sci 2017, 27, 109-128. [CrossRef]

12. Kubalíková, L.; Kirchner, K.; Bajer, A. Secondary Geodiversity and its Potential for Urban Geotourism: A Case Study from Brno City, Czech Republic. Quaest. Geogr. 2017, 36, 63-73. [CrossRef]

13. Prosser, C.D. Active quarrying and conservation. Earth Sci. Conserv. 1992, 31, 22-24.

14. Prosser, C.D.; Larwood, J. Urban site conservation-An area to build on? In Geological and Landscape Conservation; O’Halloran, D., Green, C., Harley, M., Stanley, M., Knill, J., Eds.; Geological Society: London, UK, 1994; pp. 347-352, Accession Number: WOS: A1994BB84A00068.

15. Parkes, M.; Gatley, S. Quarrying and Geoconservation in the Republic of Ireland-The Effectiveness of Guidelines for Operators. Geoheritage 2018, 10, 1-9. [CrossRef]

16. Kopecka, V.; Machar, I.; Bucek, A.; Kopecky, A. The Impact of Climate Changes on Sugar Beet Growing Conditions in the Czech Republic. Listy Cukrov. Reparske 2013, 129, 326-329.

17. Machar, I. Conservation and Management of Floodplain Forests in the Protected Landscape Area Litovelske Pomoravi (Czech Republic) Introduction. In Conservation and Management of Floodplain Forests in the Protected Landscape Area Litovelske Pomoravi (Czech Republic); Machar, I., Ed.; Palacky University: Olomouc, Czech Republic, 2009; pp. 7-108, Accession Number: WOS: 000331015800001; ISBN 978-80-244-2355-5.

18. Betard, F. Patch-Scale Relationships Between Geodiversity and Biodiversity in Hard Rock Quarries: Case Study from a Disused Quartzite Quarry in NW France. Geoheritage 2013, 5, 59-71. [CrossRef]

19. Beranova, L.; Balej, M.; Raska, P. Assessing the geotourism potential of abandoned quarries with multitemporal data (České Středohoří Mts., Czechia). GeoScape 2017, 11, 93-111. [CrossRef]

20. Kirchner, K.; Kubalikova, L.; Machar, I. Assessment of anthropogenic landforms for the geotourism purposes (case study: Velké Opatovice fortification site, Archdiocese of Olomouc, Czech Republic). In Proceedings of the Public Recreation and Landscape Protection-With Nature Hand in Hand, Mendel University in Brno, Kitiny, Czech Republic, 2-4 May 2018; pp. 61-68, Accession Number: WOS:000434239900009.

21. Machar, I.; Vozenilek, V.; Simon, J.; Pechanec, V.; Brus, J.; Fulnecek, P.; Vitek, T. Joining of the historical research and future prediction as a support tool for the assessment of management strategy for European beech-dominated forests in protected areas. Nat. Conserv. Bulg. 2017, 22, 51-78. [CrossRef]

22. Gordon, J.E. Geoheritage, Geotourism and the Cultural Landscape: Enhancing the Visitor Experience and Promoting Geoconservation. Geosciences 2018, 8, 136. [CrossRef]

23. Miles, E. Involving local communities and volunteers in geoconservation across Herefordshire and Worcestershire, UK-The Community Earth Heritage Champions Project. Proc. Geol. Assoc. 2013, 124, 691-698. [CrossRef] 
24. Kilianova, H.; Pechanec, V.; Svobodova, J.; Machar, I. Analysis of the evolution of the floodplain forests in the aluvium of the Morava river. In Proceedings of the 12th International Multidisciplinary Scientific Geoconference, SGEM 2012, Vol. IV, Albena, Bulgaria, 17-23 June 2012; pp. 1-8, Accession Number: WOS:000348535300001.

25. Swetnam, R.D.; Tweed, F.S. A tale of two landscapes: Transferring landscape quality metrics from Wales to Iceland. Land Use Policy 2018, 76, 565-576. [CrossRef]

26. López-García, J.A.; Oyarzun, R.; López Andrés, S.I.; Manteca Martínez, J. Scientific, Educational and Environmental Considerations Regarding Mine Sites and Geoheritage: A Perspective from SE Spain. Geoheritage 2011, 3, 267-275. [CrossRef]

27. Margiotta, S.; Sanso, P. Abandoned Quarries and Geotourism: An Opportunity for the Salento Quarry District (Apulia, Southern Italy). Geoheritage 2016, 9, 1-15. [CrossRef]

28. Baczyńska, E.; Lorenc, M.W.; Kaźmierczak, U. The Landscape Attractiveness of Abandoned Quarries. Geoheritage 2018, 10, 271-285. [CrossRef]

29. Mata-Perelló, J.; Carrión, P.; Molina Escobar, J.; Villas-Boas, R. Geomining Heritage as a Tool to Promote the Social Development of Rural Communities. In Geoheritage: Assessment, Protection and Management; Reynard, E., Brilha, J., Eds.; Elsevier: Amsterdam, The Netherland, 2018; pp. 167-177. ISBN 978-0-12-809531-7.

30. Evans, B.G.; Cleal, C.J.; Thomas, B.A. Geotourism in an Industrial Setting: The South Wales Coalfield Geoheritage Network. Geoheritage 2018, 10, 93-107. [CrossRef]

31. Osborne, R. Presidential Address for 1999-2000 geodiversity: "green" geology in action. Proc. Linn. Soc. New South Wales 2000, 122, 149-173, Accession Number: WOS:000169255200011.

32. Petersen, J.F. The role of roadcuts, quarries and other artificial exposures in geomorphology education. Geomorphology 2002, 47, 289-301. [CrossRef]

33. Prosser, C.D. Geoconservation, Quarrying and Mining: Opportunities and Challenges Illustrated Through Working in Partnership with the Mineral Extraction Industry in England. Geoheritage 2018, 10, $259-270$. [CrossRef]

34. Battisti, C. Habitat fragmentation, fauna and ecological network planning: Toward a theoretical conceptual framework. Ital. J. Zool. 2003, 70, 241-247. [CrossRef]

35. Salekl, L.; Sivacioglu, A.; Topacoglu, O.; Zahradnile, D.; Jerabkoval, L.; Machar, I. Crowns of Old Remnant Oak Standards. Fresenius Environ. Bull. 2017, 26, 4023-4032.

36. Simon, J.; Machar, I.; Brus, J.; Pechanec, V. Combining a growth-simulation model with acoustic-wood tomography as a decision-support tool for adaptive management and conservation of forest ecosystems. Ecol. Inf. 2015, 30, 309-312. [CrossRef]

37. UNESCO. Operational Guidelines for the Implementation of the World Heritage Convention; UNESCO: Paris, France, 2017.

38. Pica, A.; Vergari, F.; Fredi, P.; Monte, M. The Aeterna Urbs Geomorphological Heritage (Rome, Italy). Geoheritage 2015, 8, 1-12. [CrossRef]

39. Reynard, E.; Pica, A.; Coratza, P. Urban Geomorphological Heritage. An Overview. Quaestiones Geographicae 2017, 36, 7-20. [CrossRef]

40. UNESCO. Convention Concerning the Protection of the World Cultural and Natural Heritage; UNESCO: Paris, France, 1972.

41. Ahmad, S.; Jones, D. Investigating the Mining Heritage Significance for Kinta District, the Industrial Heritage Legacy of Malaysia. Procedia Soc. Behav. Sci. 2013, 105, 445-457. [CrossRef]

42. Conlin, M.V.; Jolliffe, L. Mining Heritage and Tourism: A Global Synthesis; Routledge: London, UK; New York, NY, USA, 2011; ISBN 978-0-203-86550-7.

43. Pearson, M.; Mcgowan, B. Mining Heritage Places Assessment Manual; Australian Council of National Trusts and the Australian Heritage Commission: Canberra, Australia, 2000; ISBN 0-908-19815-9.

44. Portal, C.; Kerguillec, R. The Shape of a City: Geomorphological Landscapes, Abiotic Urban Environment and Geoheritage in the Western World: The Example of Parks and Gardens. Geoheritage 2017, 67-78. [CrossRef]

45. Habibi, T.; Ponedelnik, A.A.; Yashalova, N.; Ruban, D.A. Urban geoheritage complexity: Evidence of a unique natural resource from Shiraz city in Iran. Resour. Policy 2018, 59. [CrossRef]

46. Reynard, E.; Giusti, C. The Landscape and the Cultural Value of Geoheritage. In Geoheritatge: Assessment, Protection and Management; Reynard, E., Brilha, J., Eds.; Elsevier: Amsterdam, The Netherland, 2018; pp. 147-166. ISBN 978-0-12-809531-7. 
47. Coratza, P.; Hobléa, F. The Specificities of Geomorphological Heritage. In Geoheritage: Assessment, Protection and Management; Reynard, E., Brilha, J., Eds.; Elsevier: Amsterdam, The Netherland, 2018; pp. 87-106, ISBN 978-0-12-809531-7.

48. Reynard, E.; Panizza, M. Geomorphosites: Definition, assessment and mapping. An introduction. Géomorphologie Relief Process. Environ. 2005, 11, 177-180.

49. Boukhchim, N.; Fraj, T.B.; Reynard, E. Lateral and "Vertico-Lateral” Cave Dwellings in Haddej and Guermessa: Characteristic Geocultural Heritage of Southeast Tunisia. Geoheritage 2017, 1-16. [CrossRef]

50. Pereira, P.; Pereira, D.; Alves, M. Geomorphosite assessment in Montesinho Natural Park (Portugal). Geogr. Helv. 2007, 62, 159-168. [CrossRef]

51. Reynard, E.; Perret, A.; Bussard, J.; Grangier, L.; Martin, S. Integrated Approach for the Inventory and Management of Geomorphological Heritage at the Regional Scale. Geoheritage 2015, 8, 43-60. [CrossRef]

52. Pica, A.; Luberti, G.M.; Vergari, F.; Fredi, P.; Del Monte, M. Contribution for an Urban Geomorphoheritage Assessment Method: Proposal from Three Geomorphosites in Rome (Italy). Quaest. Geogr. 2017, 36, 21-36. [CrossRef]

53. Coratza, P.; Giusti, C. Methodological proposal for the assessment of the scientific quality of geomorphosites. IL Quat. 2005, 18, 305-311.

54. Pralong, J.P. A method for assessing tourist potential and use of geomorphological sites. Géomorphologie Relief Process. Environ. 2005, 11, 189-196. [CrossRef]

55. Reynard, E.; Fontana, G.; Kozlik, L.; Scapozza, C. A method for assessing "scientific" and "additional values" of geomorphosites. Geogr. Helv. 2007, 62, 148-158. [CrossRef]

56. Pereira, P.; Pereira, D. Methodological guidelines for geomorphosite assessment. Géomorphologie Relief Process. Environ. 2010, 16, 215-222. [CrossRef]

57. Fassoulas, C.; Mouriki, D.; Dimitriou, P.; Iliopoulos, G. Quantitative Assessment of Geotopes as an Effective Tool for Geoheritage Management. Geoheritage 2012, 4, 177-193. [CrossRef]

58. Bollati, I.; Smiraglia, C.; Pelfini, M. Assessment and selection of geomorphosites and trails in the Miage Glacier area (Western Italian Alps). Environ. Manag. 2013, 51, 951-967. [CrossRef]

59. Kubalíková, L.; Kirchner, K. Geosite and Geomorphosite Assessment as a Tool for Geoconservation and Geotourism Purposes: A Case Study from Vizovická vrchovina Highland (Eastern Part of the Czech Republic). Geoheritage 2016, 8, 5-14. [CrossRef]

60. Suzuki, D.A.; Takagi, H. Evaluation of Geosite for Sustainable Planning and Management in Geotourism. Geoheritage 2017, 1-13. [CrossRef]

61. Uña-Álvarez, E.D.; Álvarez Vázquez, M.Á.; Cuquejo-Bello, M.D.C. Landform values for rural sustainability: Recognition and assessment in a Spanish-Portuguese border region case study. Morav. Geogr. Rep. 2017, 25, 257-270. [CrossRef]

62. Peña, L.; Monge-Ganuzas, M.; Onaindia, M.; De Manuel, B.F.; Mendia, M. A Holistic Approach Including Biological and Geological Criteria for Integrative Management in Protected Areas. Environ. Manag. 2017, 59, 325-337. [CrossRef]

63. Rypl, J.; Kirchner, K.; Ryplova, R. Contribution to the Assessment of Geomorphosites in the Czech Republic (a Case Study of the North-eastern Part of the Novohradské Mountains). Geoheritage 2019, 11, 427-439. [CrossRef]

64. Bruschi, V.M.; Cendrero, A.; Cuesta-Albertos, J. A Statistical Approach to the Validation and Optimisation of Geoheritage Assessment Procedures. Geoheritage 2011, 3, 131-149. [CrossRef]

65. Kubalíková, L. Geomorphosite assesment for geotourism purposes. Czech J. Tour. 2013, 2, 80-104. [CrossRef]

66. Štrba, L.; Rybár, P.; Baláž, B.; Molokáč, M.; Hvizdák, L.; Kršák, B.; Lukáč, M.; Muchová, L.; Tometzová, D.; Ferenčíková, J. Geosite assessments: Comparison of methods and results. Curr. Issues Tour. 2015, 18, 496-510. [CrossRef]

67. Brilha, J. Inventory and Quantitative Assessment of Geosites and Geodiversity Sites: A Review. Geoheritage 2016, 8, 119-134. [CrossRef]

68. Zwolinski, Z.; Najwer, A.; Giardino, M. Methods for assessing geodiversity. In Geoheritage: Assessment, Protection and Management; Reynard, E., Brilha, J., Eds.; Elsevier: Amsterdam, The Netherland, 2018; pp. 27-52. ISBN 978-0-12-809531-7.

69. Panizza, M.; Piacente, S. Geomorphosites: A bridge between scientific research, cultural integration and artistic suggestion. Quaternario 2005, 18, 3-10. 
70. Panizza, M.; Piacente, S. Geomorphosites and geotourism. Rev. Geográfica Acadêmica 2008, 2, 5-9. [CrossRef]

71. Newsome, D.; Dowling, R. Geotourism: The Tourism of Geology and Landscape; Goodfellow Pub Ltd.: Oxford, UK, 2010; ISBN 978-1-906884-09-3.

72. Dowling, R.K. Global geotourism-An emerging form of sustainable tourism. Czech J. Tour. 2013, 2, 59-79. [CrossRef]

73. Hose, T. 3G's for Modern Geotourism. Geoheritage 2012, 4, 7-24. [CrossRef]

74. Linstone, H.A.; Turoff, M. Delphi: A brief look backward and forward. Technol. Forecast. Soc. Chang. 2011, 78, 1712-1719. [CrossRef]

75. Battisti, C.; Luiselli, L. Selecting focal species in ecological network planning following an expert-based approach: Italian reptiles as a case study. J. Nat. Conserv. 2011, 19, 126-130. [CrossRef]

76. Amici, V.; Geri, F.; Battisti, C. An integrated method to create habitat suitability models for fragmented landscapes. J. Nat. Conserv. 2010, 18, 215-223. [CrossRef]

77. Prosser, C.; Bridgland, D.R.; Brown, E.; Larwood, J. Geoconservation for science and society: Challenges and opportunities. Proc. Geol. Assoc. Proc. Geol. Assoc. 2011, 122, 337-342. [CrossRef]

78. Farsani, N.T.; de Carvalho, C.N.; Xu, K. Education as a key tenet of geotourism. In Handbook of Geotourism; Dowling, R.K., Newsome, D., Eds.; Edward Elgar Publishing: Cheltenham, UK, 2018; pp. 234-243. [CrossRef]

79. Panizza, M. Geomorphosites: Concepts, methods and examples of geomorphological survey. Chin. Sci. Bull. 2001, 46, 4-6. [CrossRef]

80. Salafsky, N.; Salzer, D.; Stattersfield, A.J.; Hilton-Taylor, C.; Neugarten, R.; Butchart, S.H.M.; Collen, B.; Cox, N.; Master, L.L.; O'Connor, S.; et al. standard lexicon for biodiversity conservation: Unified classifications of threats and actions. Conserv. Biol. 2008, 22, 897-911. [CrossRef]

81. Novák, Z. Geologická Mapa 1:50 000 List 24-32; Český Geologický Ústav: Brno, Czech Republic, 1991.

82. Müller, P.; Novák, Z. Geologie Brna a Okolí; Český geologický ústav Praha: Praha, Czech Public, 2000; ISBN 80-7075-416-8.

83. Kovarik, P.; Kutal, M.; Machar, I. Sheep and wolves: Is the occurrence of large predators a limiting factor for sheep grazing in the Czech Carpathians? J. Nat. Conserv. 2014, 22, 479-486. [CrossRef]

84. Demek, J.; Mackovčin, P.; Balatka, B.; Buček, A.; Culek, M.; Čermák, P.; Dobiáš, D.; Havlíček, M.; Hrádek, M.; Kirchner, K.; et al. Zeměpisný Lexikon ČR. Hory a Níziny; Mendelova univerzita v Brně: Brno, Czech Public, 2015; ISBN 978-80-7509-113-0.

85. Machar, I.; Vozenilek, V.; Kirchner, K.; Vlckova, V.; Bucek, A. Biogeographic model of climate conditions for vegetation zones in Czechia. Geografie 2017, 122, 64-82.

86. Parma, D.; Vejrostova, L.; Lisa, L.; Bajer, A.; Pacina, J.; Gottvald, Z. Neolithic Occupation of Svratka Alluvial Plain; Case Study from Brno-Př́zřenice, Czech Republic. Interdiscip. Archaeol. 2015, 6, 181-193. [CrossRef]

87. Lisa, L.; Peska, M.; Merta, D.; Gregor, M. Maintenance of Underground Granaries in Medieval Towns; Case Study from Padowetz, Brno, Czech Republic. Interdiscip. Archaeol. 2017, 8, 157-165. [CrossRef]

88. Machar, I.; Simon, J.; Rejsek, K.; Pechanec, V.; Brus, J.; Kilianova, H. Assessment of Forest Management in Protected Areas Based on Multidisciplinary Research. Forests 2016, 7, 11. [CrossRef]

89. Brus, J.; Pechanec, V.; Machar, I. Depiction of uncertainty in the visually interpreted land cover data. Ecol. Inform. 2018, 47, 10-13. [CrossRef]

90. Machar, I. Attempt to Summarize the Problems: Is a Sustainable Management of Floodplain Forest Geobiocenoses Possible? In Biodiversity and Target Management of Floodplain Forests in the Morava River Basin (Czech Republic); Machar, I., Ed.; Palacky University: Olomouc, Czech Republic, 2010; pp. 189-226. ISBN 978-80-244-2530-6.

91. Nehyba, S.; Kirchner, K.; Tomanová-Petrová, P. Nové odkryvy fluviálních sedimentů v prostoru Brno- Bystrc. Geologické Výzkumy na Moravě a ve Slezsku v Roce 2008, 2007, 36-40.

92. Powell, J.H.; Nash, G.; Bell, P. GeoExposures: Documenting temporary geological exposures in Great Britain through a citizen-science web site. Proc. Geol. Assoc. 2013, 124, 638-647. [CrossRef]

93. Dunlop, L. Rescue Geology-Taking Advantage of Temporary Exposures. In Proceedings of the 20th EGU General Assembly, EGU2018, Vienna, Austria, 4-13 April 2018; p. 16264.

94. Florenzano, A.; Mercuri, A.M.; Fornaciari, R.; Garcea, E.A.A. Plants, water and humans: Pollen analysis from Holocene archaeological sites on Sai Island, northern Sudan. Palynology 2019, 43, 22-33. [CrossRef] 
95. Mercuri, A.M.; Florenzano, A. The long-term perspective of human impact on landscape for environmental change (LoTEC) and sustainability: From botany to the interdisciplinary approach. Sustainability 2019, 11, 413. [CrossRef]

96. Florenzano, A. The History of Pastoral Activities in S Italy Inferred from Palynology: A Long-Term Perspective to Support Biodiversity Awareness. Sustainability 2019, 11, 404. [CrossRef]

97. Cocean, G.; Cocean, P. An Assessment of Gorges for Purposes of Identifying Geomorphosites of Geotourism Value in the Apuseni Mountains (Romania). Geoheritage 2016, 9, 71-81. [CrossRef]

98. Olafsdottir, R.; Tverijonaite, E. Geotourism: A Systematic Literature Review. Geosciences 2018, 8, 234. [CrossRef]

99. Pechanec, V.; Brus, J.; Kilianova, H.; Machar, I. Decision support tool for the evaluation of landscapes. Ecol. Inform. 2015, 30, 305-308. [CrossRef]

100. Madera, P.; Machala, M.; Slach, T.; Friedl, M.; Cernusakova, L.; Volarik, D.; Bucek, A. Predicted occurrence of ancient coppice woodlands in the Czech Republic. Iforest Biogeosci. For. 2017, 10, 788-795. [CrossRef]

(C) 2019 by the authors. Licensee MDPI, Basel, Switzerland. This article is an open access article distributed under the terms and conditions of the Creative Commons Attribution (CC BY) license (http://creativecommons.org/licenses/by/4.0/). 